\title{
Elektrikli Araçlarda Kullanılan Silindirik Lityum İyon Bataryaların Soğutulmasının Parametrik İncelenmesi
}

\author{
Ali CELEN ${ }^{1 *}$, Muhammet Yasin KABA ${ }^{1}$ \\ ${ }^{1}$ Makine Mühendisliği Bölümü, Mühendislik Fakültesi, Erzincan Binali Yıldırım Üniversitesi, Erzincan, Türkiye \\ *alicelen@erzincan.edu.tr, mykaba@yahoo.com
}

(Geliş/Received: 28/04/2020;

Kabul/Accepted: 21/10/2020)

Öz: İçten yanmalı motorlara sahip araçlarla kıyaslandıklarında çevreci olmaları sebebiyle elektrikli araçlar ön plana çıkmaya başlamıştır. Elektrikli araçların bataryalarının performansına ve ömrüne etki eden parametrelerden birisi de batarya çalışma sıcaklığıdır. Bataryaların istenilen sıcaklık seviyesinde tutulması için havayla soğutma, sıvıyla soğutma, 1sı borusuyla soğutma, faz değiştiren malzemeyle soğutma ve termoelektrik ile soğutma gibi farklı soğutma yöntemleri kullanılmaktadır. Bu çalışmada, elektrikli araçlarda kullanılan silindirik lityum iyon bataryalardan oluşan 10x10 şeklinde dizilmiş bir batarya grubu göz önüne alınmış ve bataryaların havayla ve elektriksel olarak yalıtkan olan sıvıyla (Novec 7200) soğutulması parametrik olarak incelenmiştir. Akışkan giriş sıcaklığının $\left(15^{\circ} \mathrm{C}-35^{\circ} \mathrm{C}\right)$, farklı deşarj hızlarında bataryada meydana gelen isı üretiminin (2-6 W) ve Reynolds sayısının (22559-67678) ortalama batarya sıcaklığına ve basınç kaybına etkisi araştırılmıştır. Yapılan hesaplamalar sonunda hava sıcaklığının $15^{\circ} \mathrm{C}$ üzerine çıktığı hava şartlarında doğrudan soğutmanın yeterli olmadığı bu sebeple sıvı soğutmanın kullanılmasının gerekli olduğu belirlenmiștir. Buna ek olarak, sabit Reynolds sayılarında hava ve sıvı soğutma kullanımı ile ortaya çıkacak basınç kayıpları hesaplanmıştır. Sabit Reynolds sayıları için sıvı hızının hava hızından daha düşük olması sebebiyle, hava ve sıvı soğutma şartlarında basınç kaybında ciddi bir değişim gözlemlenmemiştir.

Anahtar kelimeler: Batarya soğutma, hava ile soğutma, sıvı ile soğutma, batarya 1sıl yönetimi, elektrikli araçlar.

\section{Parametric Investigation of Cooling of Cylindrical Lithium Ion Batteries Used in Electric Vehicles}

\begin{abstract}
Electric vehicles have come to the forefront compared to vehicles having internal combustion engines since they are environmentally friendly. One of the parameters affecting electric vehicle battery performance is battery operation temperature. Different cooling methods such as air cooling, liquid cooling, heat pipe cooling, phase change material cooling and thermoelectric cooling are used in order to maintain battery temperature in desired temperature. In this study, a battery group which composed of cylindrical lithium ion batteries arranged as 10x10 is considered and cooling of the batteries with air and dielectric fluid (Novec 7200) is investigated parametrically. Effect of fluid inlet temperature $\left(15^{\circ} \mathrm{C}-35^{\circ} \mathrm{C}\right)$, battery heat generation during different discharge rates (2-6 W) and Reynolds number (22559-67678) on average battery temperature and pressure drop is researched. According to calculation results, air cooling is not sufficient for the conditions for air having temperature more than $15^{\circ} \mathrm{C}$, so it is stated that the usage of liquid cooling is necessary. In addition, pressure drop which occurred with usage air and liquid cooling is estimated. Since liquid velocity is lower than air velocity for constant Reynolds numbers, it is observed that there is no significant change in pressure drop air and liquid cooling conditions.
\end{abstract}

Key words: Battery cooling, air cooling, liquid cooling, battery thermal management, electric vehicle.

\section{Giriş}

Günümüzde ulaşım sektöründe kullanılan araçlar küresel ısınmaya yol açan sera gazı emisyonlarının en önemli sebeplerinden biri haline gelmiştir. İçten yanmalı motorların kullanıldığı araçlar çevreye karbondioksit, karbonmonoksit, hidrokarbonlar, nitrojen oksitler ve su yaymaktadır. Elektrikli araçların küresel sera gazı salınımının düşürülmesi adına bir çözüm sağlayacak olması araştırmacıları bu konuda çalışmaya yönlendirmiştir. Elektrikli araçların kullanılmasıyla egzoz emisyonları düşük ve sessiz bir ortam sağlanmasının yanı sıra içten yanmalı motorlara kıyasla daha düşük maliyetli işletme koşullarına sahip araçların geliştirilmesi planlanmaktadır [1].

Ülkemizde 2015, 2016, 2017, 2018 yıllarında sırasıyla 106, 950, 4451, 3876 adet hibrit araç satılmış olup aynı yıllarda \%100 elektrikli araç satışı sırasıyla 119, 44, 77, 155 olarak belirlenmiştir [2]. Bu durum ülkemizde hibrit araçların elektrikli araçlara kıyasla daha çok tercih edildiğini göstermektedir.

Elektrikli araçlar genel olarak büyük hacim kaplayan bir batarya paketi, elektrik motoru ve rejeneratif frenleme sisteminden oluşurken, hibrit araçlar ise küçük hacim kaplayan bir batarya paketi elektrik motoru,

\footnotetext{
* Sorumlu yazar: alicelen @ erzincan.edu.tr. Yazarların ORCID Numarası: ${ }^{*}$ 0000-0003-3593-5183, ${ }^{1}$ 0000-0001-7880-7259
} 
rejeneratif frenleme sistemi, içten yanmalı bir motor ve yakıt tankından oluşmaktadır. Hibrit araçlarda elektrik güçlerine göre mikro hibrit, küçük hibrit, tam hibrit ve şarjlı hibrit olarak sınıflandırılmaktadır [3].

Bir elektrikli aracı oluşturan en önemi elemanlardan birisi bataryadır, bu sebeple uygun batarya tipinin seçimi büyük önem taşımaktadır. Farklı batarya tipleri göz önüne alındığında kurşun asit, nikel-kadmiyum, nikel-metal hibrit, lityum iyon, lityum iyon polimer, lityum iyon fosfat, çinko hava, lityum sülfür ve lityum hava tipi bataryalar elektrikli araçlarda kullanılabilecek bataryalar olarak ön plana çıkmaktadırlar. Bu bataryalar arasından lityum iyon bataryalar yüksek enerji yoğunluğu (118-250 Wh/kg), yüksek hacimsel enerji yoğunluğu (200-400 Wh/L), yüksek özgül güç (200-430 W/kg), yüksek çevrim ömrü (2000) ve uygun çalışma sıcaklığı $\left(-20-60^{\circ} \mathrm{C}\right)$ gibi özellikleri ile elektrikli araçlarda kullanılması en uygun batarya olarak görülmektedir [4]. Elektrikli araçlarda kullanılan lityum iyon bataryalar genellikle silindirik veya prizmatik geometrik özelliklere sahip olup birbirlerine seri veya paralel bağlanılarak gruplar, modüller ve batarya paketleri oluşturulmaktadır. Hücre olarak adlandırılan tekli bataryaların birbirlerine bağlanmasıyla gruplar, grupların birbirlerine bağlanmasıyla modüller, modüllerin birbirlerine bağlanmasıyla ise batarya paketleri oluşmaktadır. Şekil 1'de silindirik lityum iyon batarya kullanılarak oluşturulan Tesla marka araca ait batarya paketi görülmektedir. Şekil 1'den görüleceği üzere, bir adet batarya $3.75 \mathrm{~V}$ gerilime, 3.1 Ah akıma ve $11.625 \mathrm{Wh}$ güce sahiptir. 74 adet pilin birbirine paralel bağlanması sonucu bir adet grup oluşur ve bu grup $3.75 \mathrm{~V}$ gerilime, 229.4 Ah akıma ve $860.25 \mathrm{Wh}$ güce sahiptir. 6 adet grubun birbiri arasında seri bağlanması sonucu bir adet modül oluşur ve bu modül $22.5 \mathrm{~V}$ gerilime, 229.4 Ah akıma ve 5161.5 Wh güce sahiptir. 16 adet modülün birbirleri arasında seri bağlanması sonucu bir adet batarya paketi oluşur ve bu batarya paketi $360 \mathrm{~V}$ gerilime, 229.4 Ah akıma ve $82584 \mathrm{Wh}$ güce sahiptir [5].

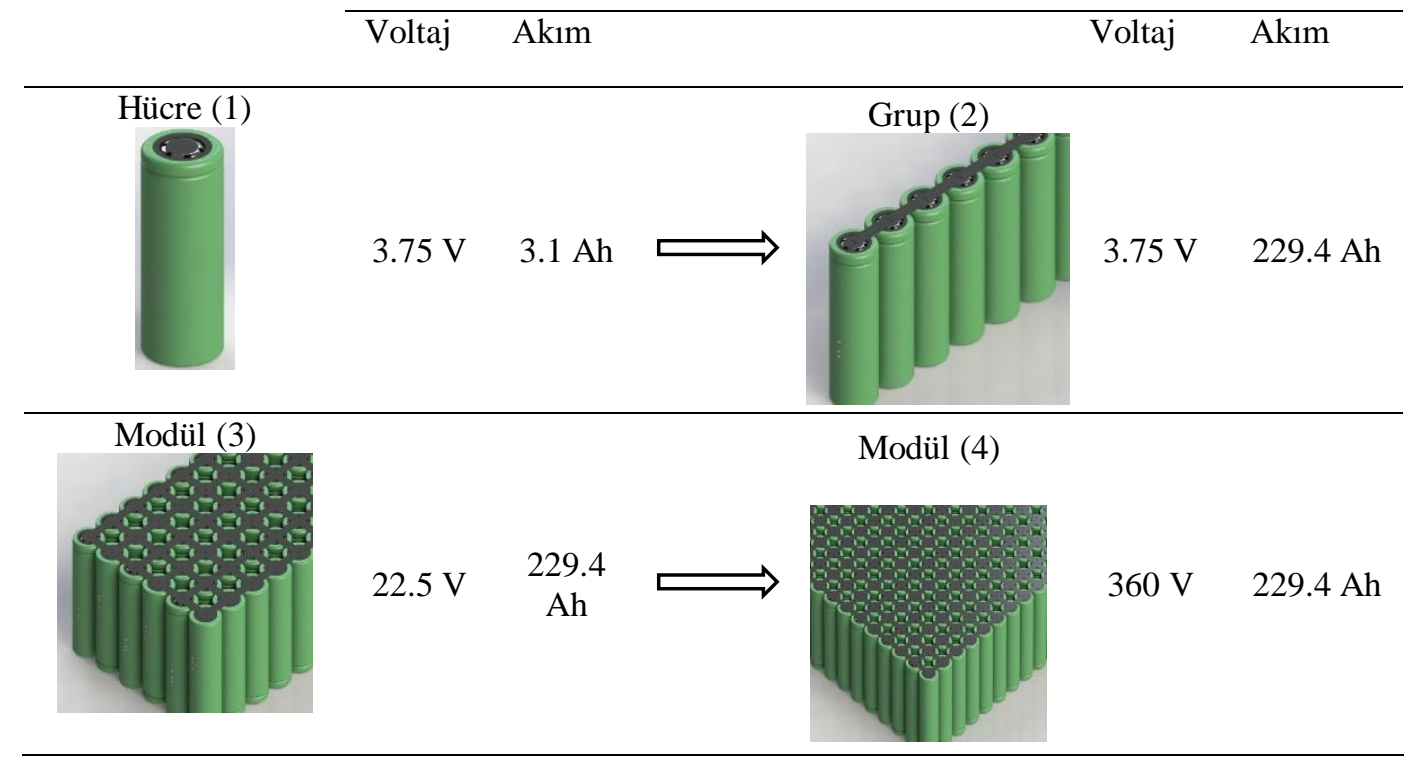

Şekil 1. Elektrikli araçlarda batarya paketi oluşumunun şematik gösterimi

Bataryaların performansını, ömrünü, güvenliğini ve maliyetini etkileyen parametrelerden birisi de çalışma sıcaklığıdır. Lityum iyon bataryalar için uygun çalışma sıcaklığ $15^{\circ} \mathrm{C}-40^{\circ} \mathrm{C}$ arasında olduğu ortaya koyulmuştur [6]. Uygun çalışma şartlarını sağlamak için yapılan batarya 1sıl yönetimi çalışmaları incelendiğinde hava ile soğutma, sıvı ile soğutma, ısı borusu ile soğutma, faz değiştiren malzeme ile soğutma ve termoelektrik soğutma gibi farklı yöntemler olduğu görülmektedir. Bu yöntemlerin avantaj ve dezavantajları Tablo 1'de verilmiştir [7]. Uygulamada bu yöntemler arasında en çok sıvı ve hava ile soğutma kullanılmaktadır. Düşük ısıl yüklerde sıvı soğutma ile kıyaslandığında düşük özgül ısınma ısısı ve verim dezavantajlarına rağmen doğrudan temas, hafiflik, kolay bakım ve düşük maliyet özellikleri ile hava ile soğutma avantajlı hale gelebilmektedir. Yüksek 1sıl yüklerde ise havaya kıyasla yüksek soğutma kapasitesi ile sıvı soğutma ön plana çıkmaktadır.

Literatürdeki silindirik lityum iyon bataryaların hava ve sıvı ile soğutulması üzerine yapılan deneysel ve nümerik çalışmaların bazıları şöyle özetlenmiştir:

Park ve Jung [8] silindirik lityum iyon bataryaların soğutulmasında hava ve sıvı (mineral yağ) kullanımının tasarım ve enerji tüketimine etkisini araştırmışlardır. Hava ile soğutmada geniş batarya modüllerinin kullanımının 
Tablo 1. Batarya 1sıl yöntemlerinin karşılaştırılması [7]

\begin{tabular}{|c|c|c|}
\hline Yöntem & Avantaj & Dezavantaj \\
\hline Hava ile soğutma & $\begin{array}{l}\text { Doğrudan temas, hafiflik, } \\
\text { kolay bakım }\end{array}$ & $\begin{array}{l}\text { Düşük özgül 1sınma 1S1s1, } \\
\text { homojen dağılımı olmamas1, } \\
\text { düşük verim }\end{array}$ \\
\hline Sıvı ile soğutma & $\begin{array}{l}\text { Yüksek özgül 1sinma 1sis1, } \\
\text { yüksek verim }\end{array}$ & $\begin{array}{l}\text { Yüksek maliyet, kaçak sorunu, } \\
\text { karmaşık yapı }\end{array}$ \\
\hline Isı borusu ile soğutma & $\begin{array}{l}\text { Yüksek ısıl iletkenlik, yüksek } \\
\text { verim }\end{array}$ & Yüksek maliyet, karmaşık yapı \\
\hline $\begin{array}{l}\text { Faz değiştiren ile } \\
\text { malzeme soğutma }\end{array}$ & $\begin{array}{l}\text { Düşük maliyet, } \\
\text { sıcaklık } \\
\text { verim }\end{array}$ & $\begin{array}{l}\text { Düşük 1sıl iletkenlik, kaçak } \\
\text { sorunu }\end{array}$ \\
\hline $\begin{array}{l}\text { Termoelektrik ile } \\
\text { soğutma }\end{array}$ & $\begin{array}{l}\text { Hareketsiz ve sessiz olması, } \\
\text { Bakım maliyeti düşük, uzun } \\
\text { ömürlü }\end{array}$ & Düşük verim, ek güç ihtiyacı \\
\hline
\end{tabular}

sıvı soğutmada ise dar batarya modüllerinin kullanımının uygun olduğunu ifade etmişlerdir. Ayrıca yüksek ısıl yüklerde hava soğutmalı bataryaların sıvı soğutmalı bataryalara kıyasla daha fazla güç tükettiğini belirtmişlerdir. Hava soğutmanın düşük isıl yüklerde kullanımının uygun olduğu belirtmişler ve yüksek 1sıl yüklerde sıvı soğutmanın daha etkin bir yöntem olarak kullanılmasını önermişlerdir.

Li vd. [9] silindirik lityum iyon bataryaların hava ile soğutulmasını deneysel ve sayısal olarak araştırmışlardır. Batarya paketi içerisindeki sıcaklık dağılımını farklı çalışma şartları için belirlemiş ve en sonda bulunan bataryaların sıcaklıklılarının diğerlerine oranla yüksek olduğunu gözlemlemişlerdir. Bu sebeple sıcaklık tahmini için iki bölgeli bir modelin kullanılmasının daha doğru sonuç vereceğini ifade etmişlerdir.

Wang vd. [10] farklı şekillerde dizilmiş bataryalardan oluşan modülün ısıl performansını sayısal olarak araştırmışlardır. Kübik ve altıgen şekilde dizilmiş batarya modüllerinin dikdörtgen ve dairesel şekilde dizilenlere kıyasla daha etkin bir şekilde soğutulabildiklerini gözlemlemişlerdir. Ayrıca fanın konumlandırılmasının soğutmaya etkisinin de incelendiği çalışmada fanın batarya modülünün üst kısmına konumlanması durumunda en iyi soğutmanın sağlandığ ifade etmişlerdir.

Yang vd. [11] sıralı ve şaşırtmalı olarak dizilmiş silindirik lityum iyon pillerin hava ile soğutulmasını sayısal olarak incelemişlerdir. Piller arasındaki enine ve boyuna mesafelerin batarya paketi sıcaklığı üzerine etkisi incelenmiş olup, piller arasındaki boyuna (akış yönünde) mesafelerin artmasıyla ve enine mesafelerin azalmasıyla ortalama batarya sıcaklığının düştüğünü gözlemlemişlerdir. Homojen sıcaklık dağılımı ve güç gereksinimleri göz önüne alındığında bataryalar arasındaki en uygun enine ve boyuna mesafelerin sırasıyla $34 \mathrm{~mm}$ ve $32 \mathrm{~mm}$ olarak önermişlerdir.

Saw vd. [12] lityum iyon pillerden oluşan batarya paketinin hava ile soğutulmasını deneysel ve sayısal olarak incelemişlerdir. Çalışmada 38120 tip batarya kullanılmış olup, 24 adet pilden oluşan batarya paketi oluşturulmuş, pillerin farklı deşarj akımlarında soğutulması durumunda ortaya çıkan 1sı ve pillere ait yüzey sıcakları belirlenmiş̧ir. Bunlara ek olarak Nusselt sayısının tahmini için korelasyon geliştirilmişlerdir.

Jiaqiang vd. [13] hava giriş/ç̧ıışı konumlarının ve batarya içerisine yerleştirilen yönlendirme plakasının batarya paketinin soğutulmasına etkisi incelemişlerdir. Havanın batarya modülünün ön yüzünden girip arka yüzünden çıkması haline en uygun sıcaklık dağılımına ulaşılabileceğini belirtmişlerdir. Buna ek olarak, yönlendirme plakasının kullanımıyla havanın batarya ve batarya kabı arasına girmesi önlenmiş ve soğutma performansı artırılmışlardır.

Shahid ve Agelin-Chaab [14] batarya paketine farklı şekillerde ikincil hava girişleri eklenmesi ile sıcaklık dağılımının homojenliğini iyileştirmek için tasarımlar yapmışlar ve sıcaklık dağılımını sayısal olarak incelemişlerdir. İkincil hava girişinin üstten olduğu tasarım sayesinde ortalama batarya paketi ve ortalama maksimum sıcaklıkların sırasıyla $\% 9$ ve $\% 4$ azaldığı görülmüştür. Yeni tasarım ile havanın karışımı ve türbülans sağladığı için homojen sıcaklığı dağılımında \%39 iyileşme sağlanmışlardır. 
Fan vd. [15] sıralı, şaşırtmalı ve çapraz şekilde dizilmiş silindirik lityum iyon bataryalarda hava giriş sıcaklığının ve batarya deşarj hızının batarya ısıl yönetimine etkisini deneysel olarak incelemişlerdir. Soğutma etkinliği ve homojen sıcaklık dağılımı göz önüne alındığında sıralı dizilimin en uygun tasarım olduğunu gözlemlemişılerdir. Buna ek olarak, çapraz dizilim ile karşılaştırıldığında sıralı dizilimde \%23 daha az basınç kaybı oluştuğunu belirtmişlerdir.

Bu çalışmada elektrikli araçlarda kullanılan 18650 tip silindirik lityum iyon bataryalardan oluşan ve 10x10 şeklinde dizilmiş batarya grubunun hava ve elektriksel olarak yalıtkan olan sıvı (Novec 7200) ile soğutulması durumunda ortalama sıcaklığın ve ortaya çıkacak basınç kaybının belirlenmesi amaçlanmıştır. Batarya grubu ve batarya grubuna ait geometrik büyüklükler sırasıyla Şekil 2(a) ve Şekil 2(b)'de, batarya grubunun soğutulması

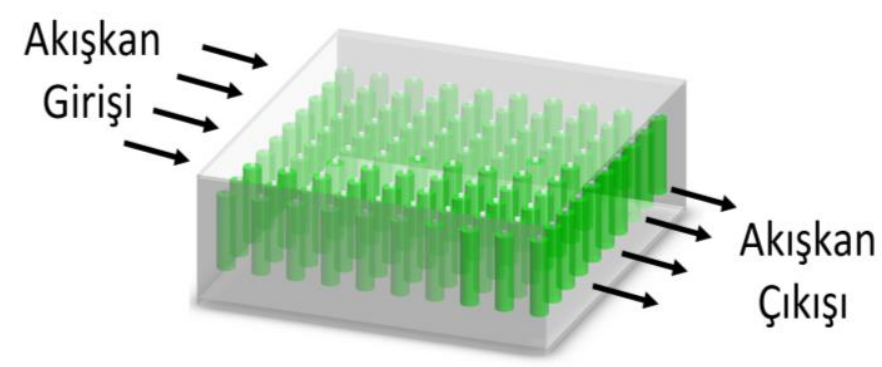

(a)

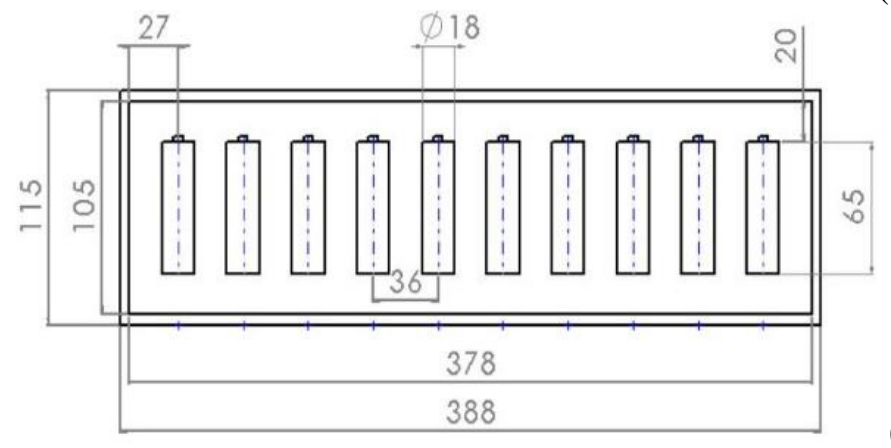

(b)

Şekil 2. Batarya grubu ve batarya grubuna ait geometrik büyüklüklerin şematik gösterimleri

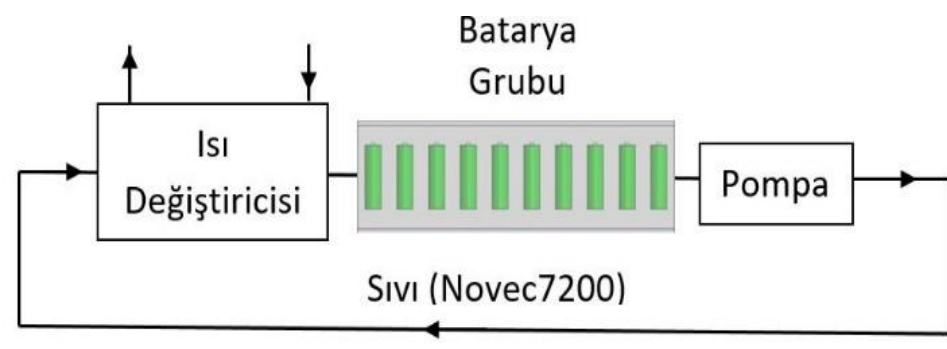

(a)

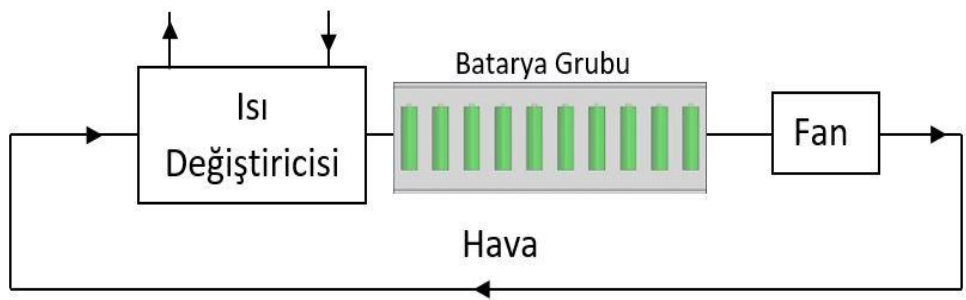

(b)

Şekil 3. Batarya grubu, batarya grubuna ait geometrik büyüklükler, hava ve sıvı soğutma sistemlerinin şematik gösterimleri 
için göz önüne alınan doğrudan temaslı hava ve sıvı temaslı soğutma sistemleri sırasıyla Şekil 3(a) ve Şekil 3(b)'de verilmiştir. Batarya grubunda akışkan giriş sıcaklığının $\left(15^{\circ} \mathrm{C}-35^{\circ} \mathrm{C}\right)$, farklı deşarj hızlarında bataryada meydana gelen 1sı üretiminin (2-6 W) ve Reynolds sayısının (22559-67678) ortalama batarya sıcaklığı ve basınç düşümü üzerine etkisi parametrik olarak araştırılmıştır.

\section{Hesaplamalar}

Silindirik bir batarya göz önüne alındığında üretilen toplam ısı üst, yan ve alt yüzeylerden taşınım yoluyla transfer edilir ve şöyle hesaplanır:

$$
\dot{Q}_{\text {batarya }}=\dot{Q}_{\ddot{u} s t}+\dot{Q}_{y a n}+\dot{Q}_{a l t}
$$

Üst ve alt yüzeyler simetrik olduğundan bu yüzeylerden transfer edilen 1sı eşit olup şöyle hesaplanır:

$$
\dot{Q}_{\text {üst }}=\dot{Q}_{a l t}=\bar{h}_{\ddot{u}} A_{\ddot{u ̈}}\left(T_{a k l s ̧ k a n}-\bar{T}_{p i l}\right)
$$

Üst ve alt yüzeylerdeki Reynolds sayısı şöyle tanımlanır:

$$
R e_{L}=\frac{V L}{\vartheta}
$$

Buradaki karakteristik uzunluk batarya paketindeki bataryaların bir sıradaki uzunluğu olup L=((nD+(ST-D) (n-1)) şeklinde tanımlanır.

Üst ve alt ortalama yüzeylerdeki ısı taşınım katsayısı aşağıdaki Nusselt denklemlerinden biri kullanılarak $\operatorname{Re}_{\mathrm{L}}<5 \times 10^{5}$ ve $5 \times 10^{5}<\operatorname{ReL}<10^{7}$ aralıkları için sırasıyla şöyle hesaplanır [16]:

$$
\begin{aligned}
& h=\frac{\overline{N u_{L}} k}{L}=0.664 \operatorname{Re}_{L}^{0.5} \operatorname{Pr}^{1 / 3} \\
& h=\frac{\overline{N u_{L}} k}{L}=0.037 \operatorname{Re}_{L}^{0.8} \operatorname{Pr}^{1 / 3}
\end{aligned}
$$

Yan yüzeyden transfer edilen ısı eşit olup şöyle hesaplanır:

$$
\dot{\mathrm{Q}}_{\mathrm{yan}}=\overline{\mathrm{h}}_{\mathrm{y}} \mathrm{A}_{\mathrm{y}}\left(\mathrm{T}_{\mathrm{akısskan}}-\overline{\mathrm{T}}_{\text {batarya }}\right)
$$

Yan yüzeylerdeki maksimum hız ve Reynolds sayısı sırasıyla şöyle tanımlanır:

$$
\begin{aligned}
& V_{\text {maks }}=\frac{S_{T}}{S_{T}-D} V \\
& R e_{L}=V_{\text {maks }} \frac{L}{\vartheta}
\end{aligned}
$$

Yan yüzeylerdeki ortalama ısı taşınım katsayısı aşağıdaki Nusselt denklemlerinden biri kullanılarak $0<\operatorname{Re}_{\mathrm{D}}<100,100<\operatorname{Re}_{\mathrm{D}}<1000,1000<\operatorname{Re}_{\mathrm{D}}<2 \times 105$ ve $2 \times 105<\operatorname{Re}_{\mathrm{D}}<10^{6}$ aralıkları için sırasılyla şöyle hesaplanır [16]:

$$
\begin{aligned}
& \bar{h}=\frac{\overline{N u}_{D} k}{D}=0.9 \operatorname{Re}_{D}^{0.4} \operatorname{Pr}^{0.36}\left(\operatorname{Pr} / \operatorname{Pr}_{s}\right)^{0.25} \\
& \bar{h}=\frac{\overline{N u}_{D} k}{D}=0.52 \operatorname{Re}_{D}^{0.5} \operatorname{Pr}^{0.36}\left(\operatorname{Pr} / \operatorname{Pr}_{S}\right)^{0.25}
\end{aligned}
$$




$$
\begin{aligned}
& \bar{h}=\frac{\overline{N u}_{D} k}{D}=0.27 \operatorname{Re}_{D}^{0.63} \operatorname{Pr}^{0.36}\left(\operatorname{Pr} / \operatorname{Pr}_{s}\right)^{0.25} \\
& \bar{h}=\frac{\overline{N u}_{D} k}{D}=0.033 \operatorname{Re}_{D}^{0.8} \operatorname{Pr}^{0.4}\left(\operatorname{Pr} / \operatorname{Pr}_{s}\right)^{0.25}
\end{aligned}
$$

Denklemler ortalama batarya sıcaklığını elde etmek için düzenlenirse şu hale gelir:

$$
\bar{T}_{\text {batarya }}=T_{\text {aklşkan }}-\frac{\dot{Q}_{\text {batarya }}}{\pi k\left(\overline{N u}_{D} H+\overline{N u}_{L} D / 2\right)}
$$

Batarya grubunda meydana gelen basınç kaybı ise şöyle hesaplanır (Cengel 2014):

$$
\Delta P=N_{L} f X \frac{\rho V_{m a k s}^{2}}{2}
$$

Burada f sürtünme faktörü olup boru demetleri için sürtünme faktörü grafiklerinden Reynolds sayısına göre belirlenmiştir [16]. Düzeltme faktörü kare dizilim için 1 olarak kabul edilmiş olup $\mathrm{N}_{\mathrm{L}}$ ise batarya sıra sayısıdır.

\section{Bulgular}

Ortalama batarya sıcaklığının hesaplanması için Denklemler (1)-(14) kullanılmış olup sabit Reynolds sayılarında akışkanların soğutma performansı belirlenmiştir. Hesaplamalarda göz önüne alınan Reynolds sayıları, akışkan hızları, kütlesel ve hacimsel debiler Tablo 2'de verilmiştir.

Tablo 2. Çalışmada kullanılan akışkanlara ait Reynolds sayıları, akışkan hızlı, kütlesel ve hacimsel debi değerleri

\begin{tabular}{llccc}
\hline Grup & Değişken & Birim & Hava & Sıv1 \\
\hline \multirow{4}{*}{1} & Reynolds sayısı & - & 22559 & 22559 \\
& Hiz & $\mathrm{m} / \mathrm{s}$ & 1 & 0.027 \\
& Kütlesel debi & $\mathrm{kg} / \mathrm{s}$ & 0.047 & 1.53 \\
& Hacimsel Debi & $\mathrm{m}^{3} / \mathrm{s}$ & 0.039 & 0.011 \\
\hline \multirow{4}{*}{2} & Reynolds sayıs1 & - & 45118 & 45118 \\
& Hiz & $\mathrm{m} / \mathrm{s}$ & 2 & 0.054 \\
& Kütlesel debi & $\mathrm{kg} / \mathrm{s}$ & 0.0956 & 3.066 \\
& Hacimsel debi & $\mathrm{m}^{3} / \mathrm{s}$ & 0.070 & 0.022 \\
\hline \multirow{4}{*}{3} & Reynolds sayıs1 & - & 67678 & 67678 \\
& Hiz & $\mathrm{m} / \mathrm{s}$ & 3 & 0.081 \\
& Kütlesel debi & $\mathrm{kg} / \mathrm{s}$ & 0.14 & 4.598 \\
& Hacimsel debi & $\mathrm{m} / \mathrm{s}$ & 0.11 & 0.032 \\
\hline
\end{tabular}

Hava ve sıvı giriş sıcaklıklarının $15^{\circ} \mathrm{C}, 25^{\circ} \mathrm{C}, 35^{\circ} \mathrm{C}$ ve batarya başına $1 \mathrm{~s}$ üretiminin $2 \mathrm{~W}$ olduğu şartlarda ortalama batarya sıcaklığının Reynolds sayısı ile değişimi sırasıyla Şekil 4(a), Şekil 4(b) ve Şekil 4(c)'de verilmiştir. Bataryanın düşük deşarj hızında çalıștığını ve düşük miktarda gücün çekildiği durumu temsil eden 2 W'llk ısı üretim değerinde hava ve sıvı ile soğutmada akışkan giriş sıcaklılarının $15^{\circ} \mathrm{C}$ ve $25^{\circ} \mathrm{C}$ olduğu durumlarda bataryaların istenilen çalışma sıcaklığı aralığında tutulabildiği görülmektedir. Hava giriş sıcaklığının $35^{\circ} \mathrm{C}$ olduğu durumda ise hava ile soğutmanın yeterli olmadığı ve sıvı ile soğutmanın ise limit değerin biraz üstünde yer aldığı görülmektedir. Buna ek olarak, artan akışkan hızı dolayısıyla Reynolds sayısı artışı ile hava ile soğutmada ortalama batarya sıcaklığında ciddi düşüşler görülürken sıvı ile soğutma durumunda ortalama batarya sıcaklığının neredeyse sabit kaldığı görülmektedir. Ortalama batarya sıcaklıklarındaki en fazla sıcaklık farkının düşük akışkan hızlarında 
Ali CELEN, Muhammet Yasin KABA

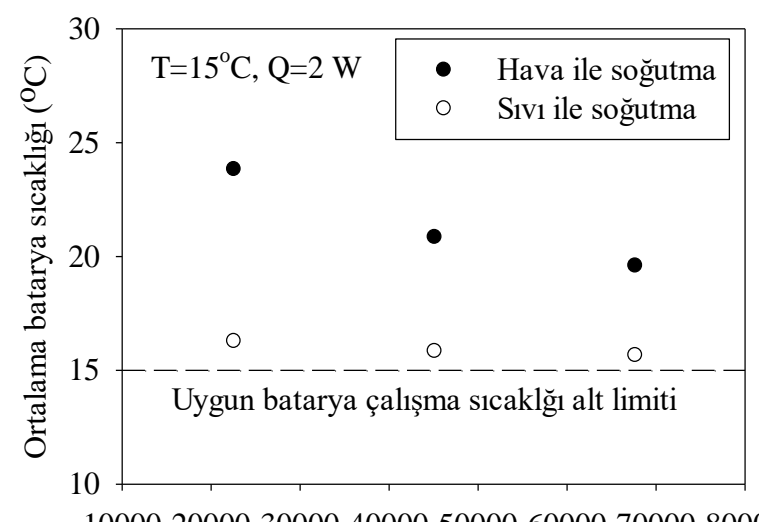

Reynolds Sayısı (-)

(a)

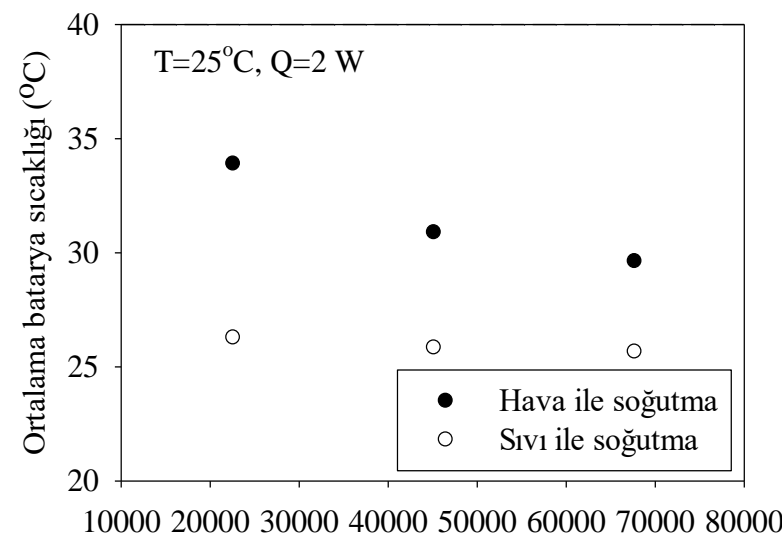

Reynolds Sayısı (-)

(b)

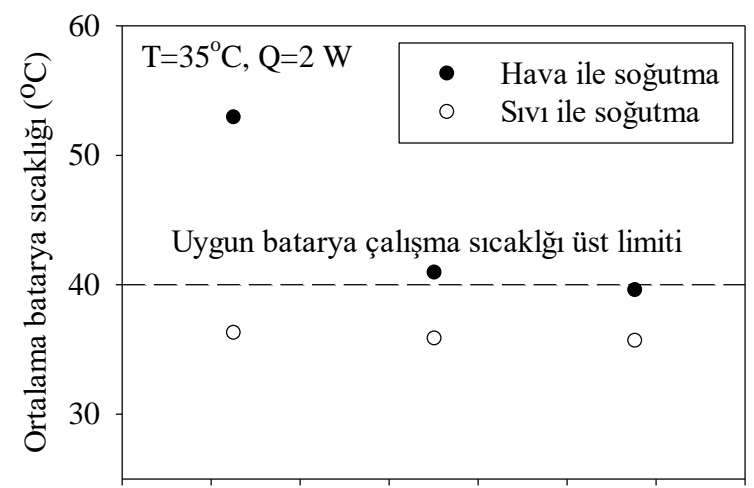

1000020000300004000050000600007000080000

Reynolds Sayısı (-)

(c)

Şekil 4. Batarya başına $2 \mathrm{~W}^{\prime}$ lik ısı üretimi ve farklı akışkan giriş sıcaklıkları için ortalama batarya sıcaklığının Reynolds sayısı ile değişimi a) $\mathrm{T}_{\text {akıskan, griş }}=15^{\circ} \mathrm{C}$, b) $\mathrm{T}_{\text {akışan, giriş }}=25^{\circ} \mathrm{C}$, c) $\mathrm{T}_{\text {akışkan, giriş }}=35^{\circ} \mathrm{C}$

olduğu gözlemlenmektedir. Maksimum sıcaklık düşümünün Şekil 4(a), Şekil 4(b) ve Şekil 4(c) için sirasıyla \%20$\% 32, \% 13-\% 22$ ve \%10-\%31 aralığında olduğu belirlenmiştir.

Hava ve sıvı giriş sıcaklıklarının $15^{\circ} \mathrm{C}, 25^{\circ} \mathrm{C}, 35^{\circ} \mathrm{C}$ ve batarya başına ısı üretiminin $4 \mathrm{~W}$ olduğu şartlarda ortalama batarya sıcaklığının Reynolds sayısı ile değişimi sırasıyla Şekil 5(a), Şekil 5(b) ve Şekil 5(c)'de verilmiştir. Bataryanın orta deşarj hızında çalıştığı durumu temsil eden orta gücün çekildiği durumu temsil eden 4 W'lık 1sı üretim değerinde sadece $15^{\circ} \mathrm{C}$ ve $25^{\circ} \mathrm{C}$ giriş sıcaklıklarında hava ve sıvı soğutma ile bataryaların istenilen çalışma sıcaklığında tutulabildiği görülmüştür. Akışkan giriş sıcaklığının $35^{\circ} \mathrm{C}$ olması durumunda hava soğutmanın yeterli olmadığı soğutmanın sıvı soğutma şeklinde yapılması gerektiği görülmüştür. Maksimum 


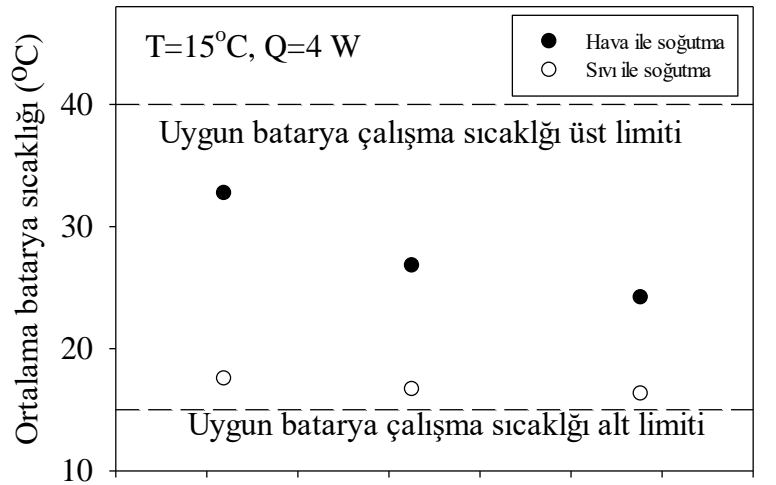

1000020000300004000050000600007000080000

Reynolds Sayısı (-)

(a)

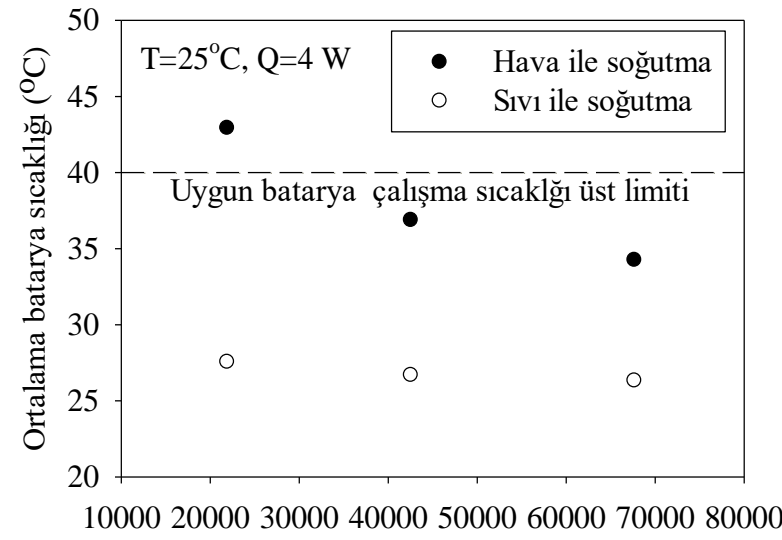

Reynolds Sayıs1 (-)

(b)

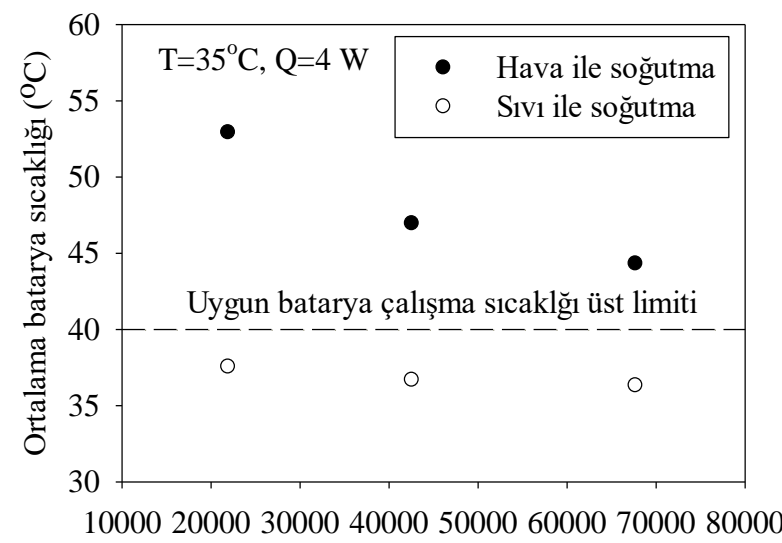

Reynolds Sayıs1 (-)

(c)

Şekil 5. Batarya başına 4 W'lik ısı üretimi ve farklı akışkan giriş sıcaklıkları için ortalama batarya sıcaklığının Reynolds sayısı ile değişimi a) $\mathrm{T}_{\text {akışkan,giriş }}=15^{\circ} \mathrm{C}$, b) $\mathrm{T}_{\text {akışkan, giriş }}=25^{\circ} \mathrm{C}$, c) $\mathrm{T}_{\text {akışkan, giriş }}=35^{\circ} \mathrm{C}$

sıcaklık düşümünün Şekil 5(a), Şekil 5(b) ve Şekil 5(c) için sırasıyla \%33-\%46, \%23-\%36 ve \%18-29 aralığında olduğu belirlenmiştir.

Hava ve sıvı giriş sıcaklıklarının $15^{\circ} \mathrm{C}, 25^{\circ} \mathrm{C}, 35^{\circ} \mathrm{C}$ ve batarya başına ısı üretiminin $6 \mathrm{~W}$ olduğu şartlarda ortalama batarya sıcaklığının Reynolds sayısı ile değişimi sırasıyla Şekil 6(a), Şekil 6(b) ve Şekil 6(c)'de verilmiştir. Bataryanın yüksek deşarj hızında çalıştığını ve dolayısıyla yüksek miktarda gücün çekildiği durumu 


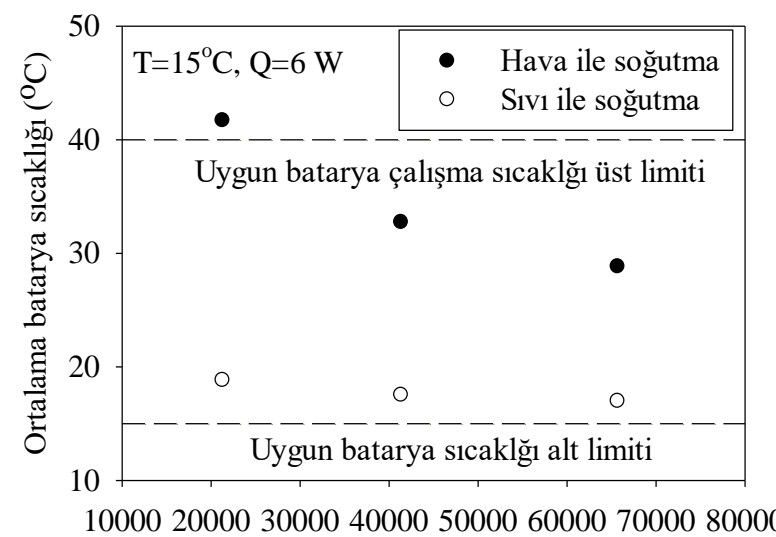

Reynolds Sayıs1 (-)

(a)

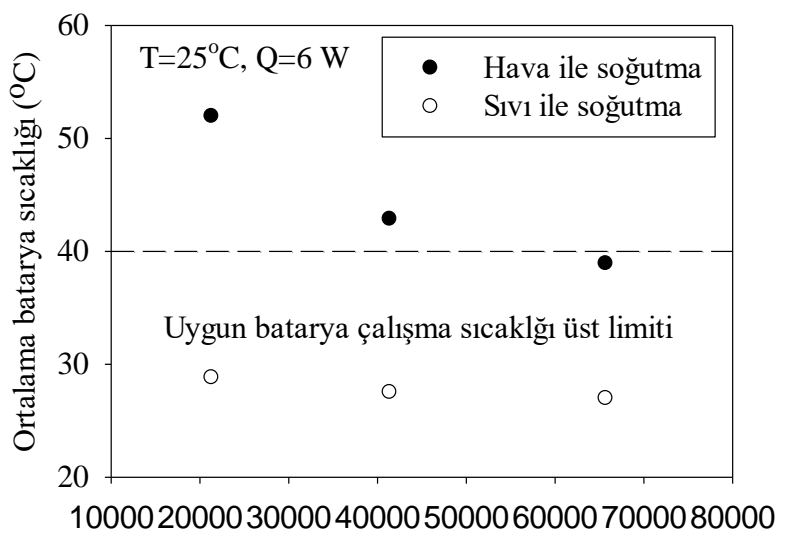

Reynolds Sayıs1 (-)

(b)

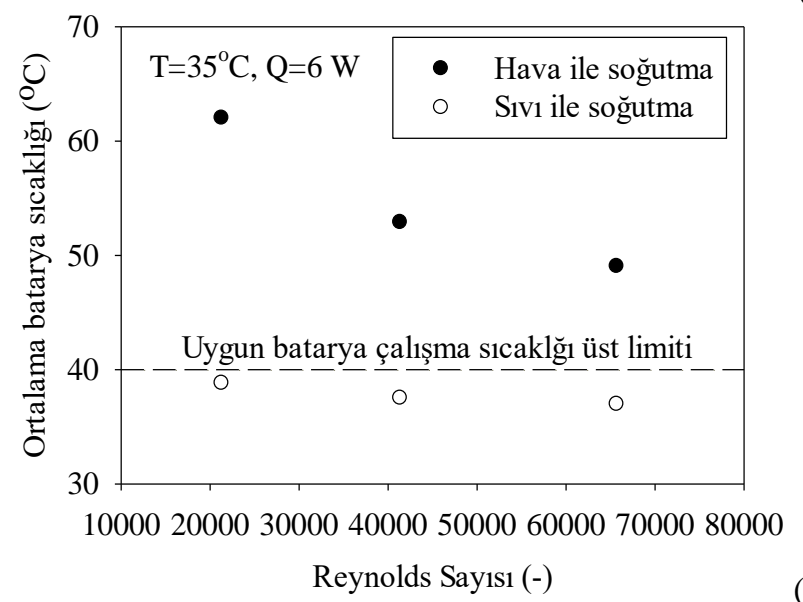

Şekil 6. Batarya başına 6 W'lik ısı üretimi ve farklı akışkan giriş sıcaklıkları için ortalama batarya sıcaklığının Reynolds sayısı ile değişimi a) $\mathrm{T}_{\text {akışkan,giriş }}=15^{\circ} \mathrm{C}$, b) $\mathrm{T}_{\text {akışkan,giriş }}=25^{\circ} \mathrm{C}$, c) $\mathrm{T}_{\text {akışkan, giriş }}=35^{\circ} \mathrm{C}$

temsil eden ortalama gücün çekildiği durumu temsil eden $6 \mathrm{~W}^{\prime}$ lık 1 sı üretim değerinde sadece $15^{\circ} \mathrm{C}$ giriş sıcaklığında en düşük hava hızı değeri dışında bataryaların istenilen çalışma sıcaklığında tutulabildiği görülmüştür.

Akışkan giriş sıcaklığında $25^{\circ} \mathrm{C}$ ve $35^{\circ} \mathrm{C}$ olduğu durumlarda sadece sıvı soğutma yeterli olurken hava soğutmanın yetersiz olduğu görülmüştür. Ortalama batarya sıcaklıklarındaki en fazla sıcaklık farkının düşük akışkan hızlarında olduğu durumda gözlemlenmektedir. Maksimum sıcaklık düşümünün Şekil 6(a), Şekil 6(b) ve Şekil 6(c) için sırasıyla \%41-55, \%31-\%45 ve \%25-\%37 olduğu belirlenmiştir. 


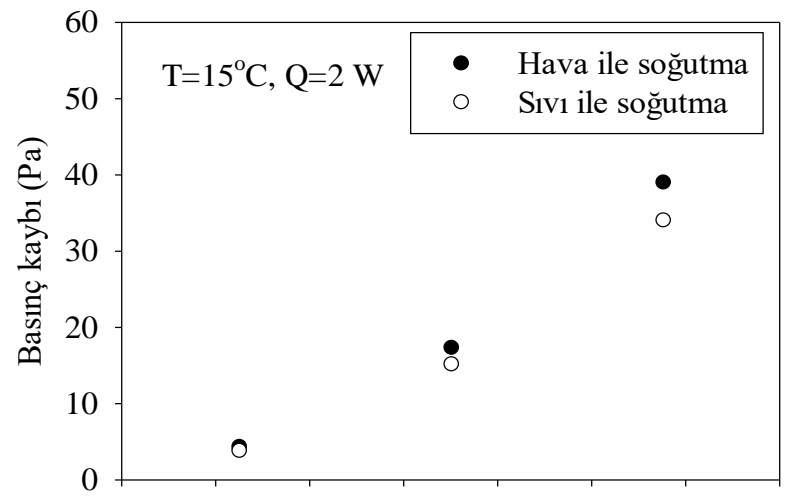

100002000030000400005000060000700008001

Reynolds sayısı (-)

(a)

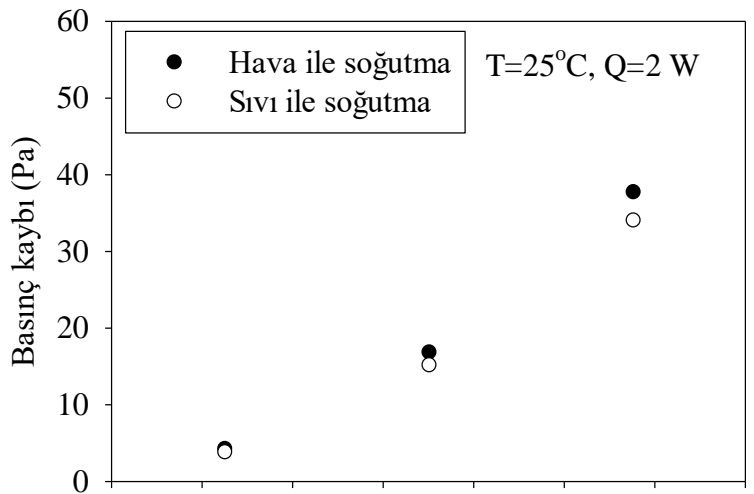

1000020000300004000050000600007000080000

Reynolds sayısı (-)

(b)

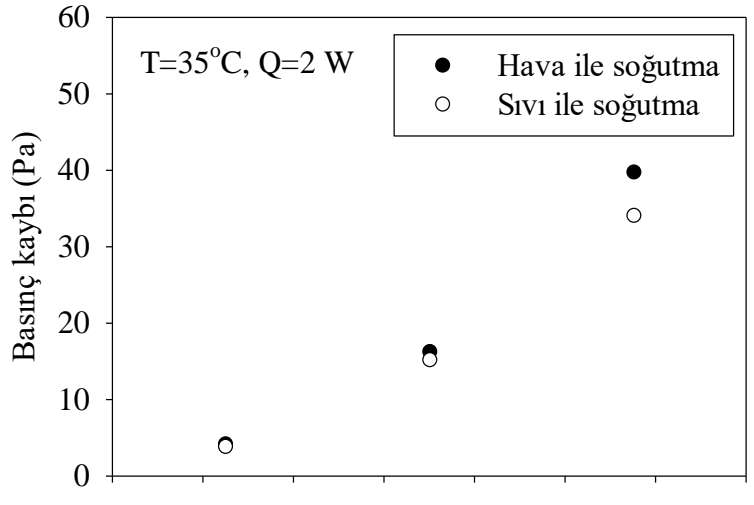

1000020000300004000050000600007000080000

Reynolds sayisı (-)

(c)

Şekil 7. Batarya başına 2 W'lik ısı üretimi ve farklı akışkan giriş sıcaklıkları için basınç kaybının Reynolds sayısı ile değişimi a) $\mathrm{T}_{\text {akışkan, giriş }}=15^{\circ} \mathrm{C}$, b) $\mathrm{T}_{\text {akışkan, giriş }}=25^{\circ} \mathrm{C}$, c) $\mathrm{T}_{\text {akışkan, giriş }}=35^{\circ} \mathrm{C}$

Bataryaların soğutulmasında 1sı transferi açısından bakıldığında sıvı soğutmanın hava soğutmaya kıyasla daha başarılı olduğu görülmektedir ancak yapılacak tasarımda kullanılan akışkan ile ortaya çıkacak basınç kaybının da belirlenmesi önemlidir. Bu sayede sistemde kullanılacak fan veya pompanın kapasiteleri uygun olarak belirlenebilir. Göz önüne alınan çalışma şartları için hava ve sıvı soğutma kullanılması durumunda batarya grubunda ortaya çıkacak basınç kayıpları Şekil 7, Şekil 8 ve Şekil 9'da verilmiştir. Şekillerden de görüleceği üzere, sıvı soğutma ile ortaya çıkacak basınç kaybının hava soğutmayla karşılaştırıldığında çok az da olsa düşüktür. Bu 
Ali CELEN, Muhammet Yasin KABA

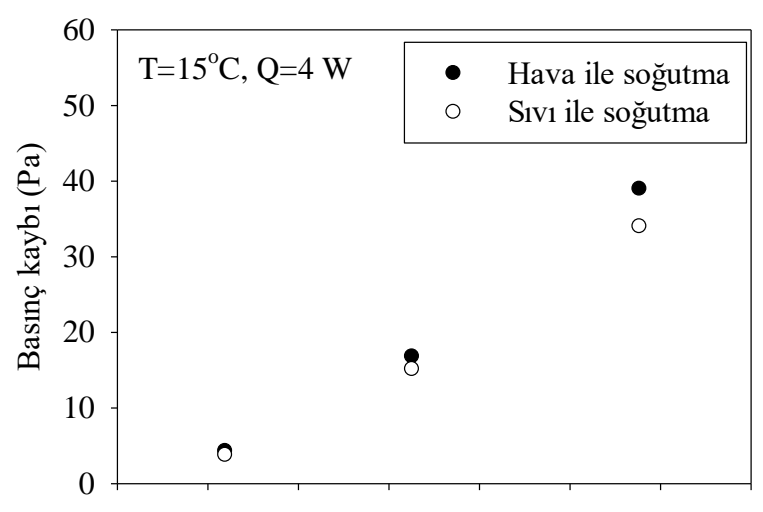

1000020000300004000050000600007000080000

Reynolds sayısı (-)

(a)

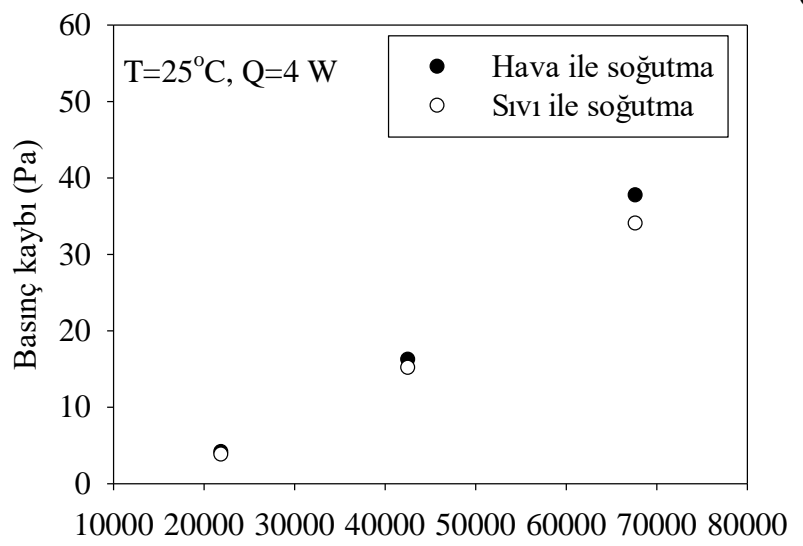

Reynolds sayisı (-)

(b)

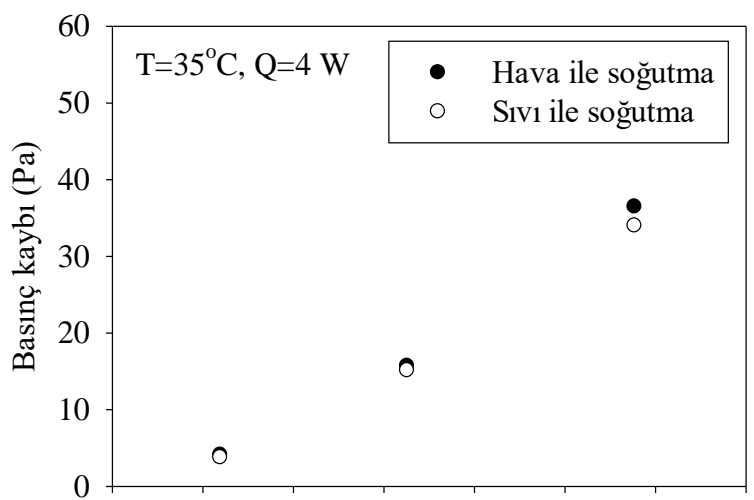

1000020000300004000050000600007000080000

Reynolds sayis1 (-)

(c)

Şekil 8. Batarya başına 4 W'lik ısı üretimi ve farklı akışkan giriş sıcaklıkları için basınç kaybının Reynolds sayısı

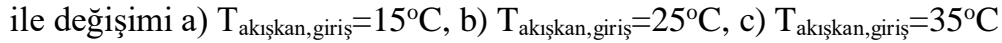

durum yoğunluğu ve viskozitesi daha yüksek olan sıvı akışkan kullanmasına rağmen, sıvı akışkanın havaya kıyasla daha düşük hızlarda kullanılması olarak açıklanabilir. 


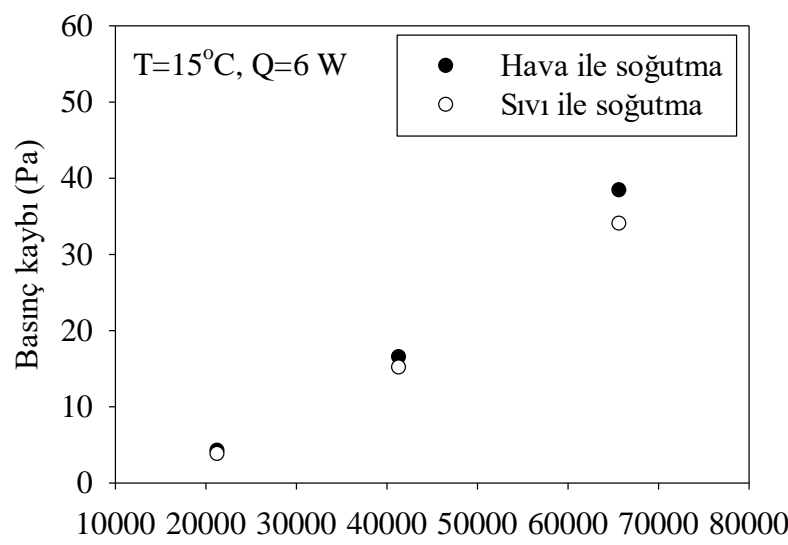

Reynolds sayıs1 (-)

(a)

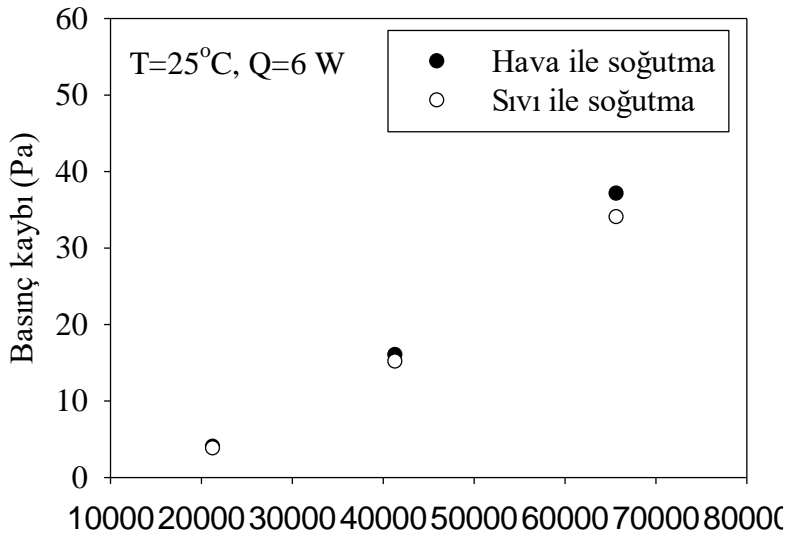

Reynolds sayıs1 (-)

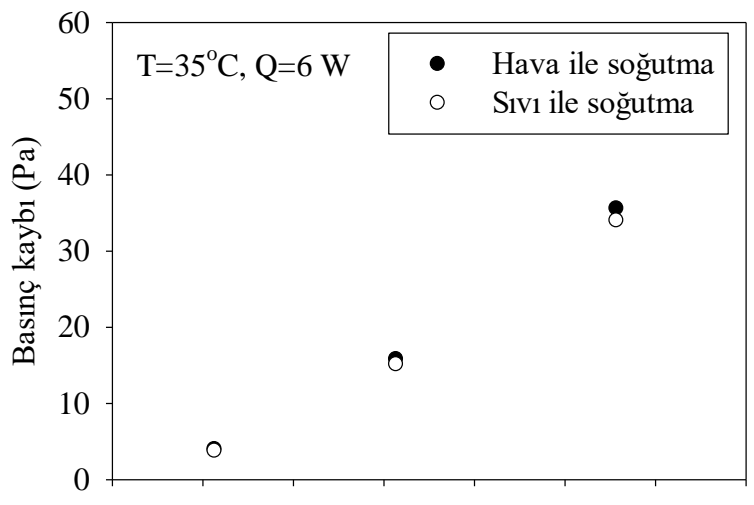

1000020000300004000050000600007000080000

Reynolds sayısı (-)

(c)

Şekil 9. Batarya başına $6 \mathrm{~W}^{\prime}$ lik ısı üretimi ve farklı akışkan giriş sıcaklıkları için basınç kaybının Reynolds sayısı ile değişimi a) $\mathrm{T}_{\text {akışkan, giriş }}=15^{\circ} \mathrm{C}$, b) $\mathrm{T}_{\text {akışskan, giriş }}=25^{\circ} \mathrm{C}$, c) $\mathrm{T}_{\text {akışkan, giriş }}=35^{\circ} \mathrm{C}$

\section{Tartışma ve Sonuç}

Elektrikli araçlarda kullanılan silindirik lityum iyon bataryaların hava ve elektriksel olarak yalıtkan olan sıvı akışkan Novec 7200 ile soğutulması durumunda ortalama batarya sıcaklığının ve ortaya çıkacak basınç kaybının araştırıldığı bu parametrik çalışmada şu sonuçlara ulaşılmıştır:

- Sıvı ile soğutmada ortalama batarya sıcaklıkları hava ile soğutmaya kıyasla daha düşük olmaktadır. 
- Düşük akışkan giriş sıcaklıklarında veya batarya ısıl yüklerinde hava soğutma yeterli olmaktadır. Yüksek akışkan giriş sıcaklıklarında veya batarya ısıl yüklerinde hava soğutma yeterli olmazken sıvı soğutma ile batarya uygun çalışma sıcaklıklarında tutulabilir.

- Batarya başına 2 W'lik 1sı üretimi durumunda hava soğutma yerine sıvı soğutma kullanılarak ortalama batarya sıcaklığında maksimum \%32'lik bir azalma meydana gelmektedir.

- Batarya başına 4 W'lik ısı üretimi durumunda hava soğutma yerine sıvı soğutma kullanılarak ortalama batarya sıcaklığında maksimum \%46’lık bir azalma meydana gelmektedir.

- Batarya başına 6 W'lik 1sı üretimi durumunda hava soğutma yerine sıvı soğutma kullanılarak ortalama batarya sıcaklığı maksimum \%55'lik bir azalma meydana gelmektedir.

- Sıvı soğutma ile ortaya çıkacak basınç kaybı hava soğutmayla karşılaştırıldığında çok az da olsa düşüktür.

- Yüksek akışkan giriş sıcaklıklarında ve batarya 1sıl yüklerindeki soğutma performansı göz önüne alındığında sıvı soğutmanın kullanımının hava soğutmaya kıyasla daha başarılı olduğu görülmektedir.

\section{Kaynaklar}

[1] Tie SF, Tan CW. A review of energy sources and energy management system in electric vehicles. Renewable Sustainable Energy Rev 2013; 20: 82-102.

[2] http://tehad.org/wp-content/uploads/2019/07/w-2019-TR_-ilk-YARI-sat\%C4\%B1\%C5\%9F-rakamla r\%C4\%B1.jpg

[3] Dincer I, Hamut HS, Javani N. Thermal Management of Electric Vehicle Battery Systems. John Wiley \& Sons, 2016.

[4] Yong, JY, Ramachandaramurthy VK., Tan KM, Mithulananthan, N.. A review on the state-of-the-art technologies of electric vehicle, its impacts and prospects. Renewable Sustainable Energy Rev 2015; 49: 365-385.

[5] Lelie M, Braun T, Knips M, Nordman,H, Ringbeck F, Zappen H, Sauer D. Battery management system hardware concepts: An overview. Appl. Sci. 2018; 8(4): 534.

[6] Wang Q, Jiang B, Li B, Yan, Y. A critical review of thermal management models and solutions of lithium-ion batteries for the development of pure electric vehicles. Renewable Sustainable Energy Rev 2016; 64: 106-128.

[7] Siddique ARM, Mahmud S, Van Heyst B. A comprehensive review on a passive (phase change materials) and an active (thermoelectric cooler) battery thermal management system and their limitations. J. Power Sources 2018; 401: $224-237$.

[8] Park S, Jung D. Battery cell arrangement and heat transfer fluid effects on the parasitic power consumption and the cell temperature distribution in a hybrid electric vehicle. J. Power Sources 2013; 227: 191-198.

[9] Li X, He F, Ma L. Thermal management of cylindrical batteries investigated using wind tunnel testing and computational fluid dynamics simulation. J. Power Sources 2013; 238: 395-402.

[10] Wang T, Tseng KJ, Zhao J, Wei Z. Thermal investigation of lithium-ion battery module with different cell arrangement structures and forced air-cooling strategies. Appl. Energy 2014; 134: 229-238.

[11] Yang N, Zhang X, Li G, Hua D. Assessment of the forced air-cooling performance for cylindrical lithium-ion battery packs: A comparative analysis between aligned and staggered cell arrangements. Appl. Therm. Eng. 2015; 80: 55-65.

[12] Saw LH, Ye Y, Tay AA, Chong WT, Kuan SH, Yew MC. Computational fluid dynamic and thermal analysis of lithiumion battery pack with air cooling. Appl. Energy 2016; 177: 783-792.

[13] Jiaqiang E, Yue M, Chen J, Zhu H, Deng Y, Zhu Y, Zhang F, Wen M, Zhang B, Kang S. Effects of the different air cooling strategies on cooling performance of a lithium-ion battery module with baffle. Appl. Therm. Eng. 2018; 144: 231241.

[14] Shahid S, Agelin-Chaa, M. Development and analysis of a technique to improve air-cooling and temperature uniformity in a battery pack for cylindrical batteries. Therm Sci Eng Prog 2018; 5: 351-363.

[15] Fan Y, Bao Y, Ling C, Chu Y, Tan X, Yang S. Experimental study on the thermal management performance of air cooling for high energy density cylindrical lithium-ion batteries. Appl. Therm. Eng. 2019; 155: 96-109.

[16] Cengel Y. Heat and Mass Transfer: Fundamentals and Applications. McGraw-Hill Higher Education, 2014. 